Case Study

\title{
Efficacy of Shadbindu Ghrita Nasya (Nasal Medication) in Vataja Pratishyaya/ Allergic Rhinitis: A Case Study
}

\author{
Swapna Alva', G Shrinivasa Acharya', Ashwini M] ${ }^{3}$
}

${ }^{1}$ PhD Scholar \& Professor, ${ }^{3}$ Professor \& Head, Department of Shalakyatantra, ${ }^{2}$ Principal, Sri Dharmasthala Manjunatheshwara College of Ayurveda \& Hospital, Kuthpady, Udupi, Karnataka, India.

DOI: https://doi.org/10.24321/2394.6547.202005

\section{I $\quad \mathbf{N} \quad \mathbf{F} \quad \mathbf{O}$}

\section{Corresponding Author:}

Swapna Alva, Department of Shalakyatantra, Sri Dharmasthala Manjunatheshwara College of Ayurveda \& Hospital, Kuthpady, Udupi, Karnataka, India.

E-mail Id:

sdbshalakya@gmail.com

Orcid Id:

https://orcid.org/0000-0002-3799-9829

How to cite this article:

Alva S, Acharya GS, Ashwini MJ. Efficacy of Shadbindu Ghrita Nasya (Nasal Medication) in Vataja Pratishyaya/ Allergic Rhinitis: A Case Study. J Adv Res Ayur Yoga Unani Sidd Homeo 2020; 7(3\&4): 1-3.

Date of Submission: 2020-09-12

Date of Acceptance: 2020-10-03

\section{$\begin{array}{llllllll}\mathbf{A} & \mathbf{B} & \mathbf{S} & \mathbf{T} & \mathbf{R} & \mathbf{A} & \mathbf{C} & \mathbf{T}\end{array}$}

Background: Vataja pratishyaya is a disease affecting the nasal cavity. The clinical features of vataja pratishyaya include anaddha nasa (nasal obstruction), pihita nasa (stuffy nose), tanusarava (thin, watery discharge), bhrisha kshava (excessive sneezing), shirovyatha (headache), swarpopaghata (change of voice) and chirapaka (chronic perpetuation). Due to the similarity in symptomatology, the disease is compared to allergic rhinitis in modern parlance. Sushruta mentions snehana type of navana nasya to treat vataja pratishyaya/allergic rhinitis and emphasises the importance of optimal dose measured as per magadga mana to treat these conditions. In this paper, a case of vataja pratishyaya/allergic rhinitis and its management with shadbindu ghrita nasya with a textual dose of $12 \mathrm{ml}$ to each nostril is discussed.

Methods: The patient suffering from vataja pratishyaya/allergic rhinitis was treated with 2 courses of Shadbindu ghrita nasya, each course consisting of one sitting per day for 7 days. In each sitting $12 \mathrm{ml}$ of shadbindu ghrita was poured into each nostril.

Result: Patient's clinical status was assessed on $7^{\text {th }}, 21^{\text {st }}$ and $28^{\text {th }}$ day. Remission of symptoms like sneezing, rhinorrhoea, nasal pruritus, nasal congestion, itching in the eyes, and palate was observed after first course of nasya and on $21^{\text {st }}$ day. Complete remission of almost all symptoms was observed after 2 courses of treatment. Patient was followed up for 4 months and no recurrence of symptoms observed.

Conclusion: A case of vataja pratishyaya/allergic rhinitis outlines a clear history and resolution of symptoms and signs following 2 courses of shadbindu ghrita nasya for 7 days administered as per snehana nasya schedule is very effective in complete resolution of symptoms in vataja pratishyaya/allergic rhinitis.

Keywords: Vataja Pratishyaya, Allergic Rhinitis, Shadbindu Ghrita 


\section{Description}

A 21-year-old Hindu undergraduate student from Udupi presented to Shalakyatantra OPD with a history of profuse runny nose, repeated bouts of sneezing (50-60/day), nasal pruritus, nasal congestion from last 10 years. He also complained of itching in the eyes and palate and change of voice. There was no history of fever, chills, heaviness of head and shortness of breath. The symptoms would aggravate on exposure to dust, household dust, domestic smoke, animal dander, by using clothes kept in cupboard for long, cold climate, freeze items, mechanical irritation, washing face with cold water, fan blowing on face, and lack of sleep. Sometimes, the symptoms would increase after waking up in the morning. Patient would feel better during summer season. The sleep was disturbed due to nasal obstruction. The patient would get relief only after taking medicines. The patient was treated for allergic rhinitis with oral antihistamines and corticosteroids by his family doctor. His past history revealed that patient had similar symptoms from 10 years. Patient was not a known case of hypertension, diabetes mellitus. There was no cyanosis or clubbing or oedema. Family history was positive for his father and elder sister with allergic rhinitis and his mother was a known case of bronchial asthma since childhood. On physical examination his vital signs were-BP: $130 / 80 \mathrm{~mm}$ $\mathrm{Hg}$, respiratory rate: $15 / \mathrm{min}$, weight: $68 \mathrm{~kg}$. Conjunctiva was congested, tympanic membrane was retracted but intact, the nasal mucosa was boggy and congested. The inferior turbinates and middle turbinate of right nasal cavity were swollen. On chest auscultation, there was no ronchi or crepitations. The routine blood investigation showed the following: haemoglobin: $12.3 \mathrm{Gm} \%$, TC WBC: 10,400, neutrophils: $42 \%$, lymphocytes: $34 \%$, eosinophills: 08\%, monocytes: 04\%, basophils: 00, ESR: 12 mmUhour and AEC: 468.0 cells/cu.mm. It was diagnosed as vataja pratishyaya/allergic rhinitis based on dosha and dushya, and allergic rhinitis on the basis of history and clinical examination and severity of allergic rhinitis was 16 which was assessed as per the criteria for score for allergic rhinitis of Annesi-Maesano et al.

Confirming the fitness of the patient for nasya karma the patient was started with nasya with Shadbindu Ghrita by adopting the Snehana Navana type of Nasya schedule with a dose of $12 \mathrm{ml}$ to each nostril for 7 days. After completion of Nasya for 7 days, the severity of illness was assessed and the patient was asked to come for next course of treatment with Shadbindu Ghrita Nasya $12 \mathrm{ml}$ to each nostril on $21^{\text {st }}$ day. The $2^{\text {nd }}$ course of Nasya was done for 7 days. No concurrent oral medication was prescribed during this period.

\section{Method of Administration of Nasya'}

The materials required for nasya are as follows: a) Tila
Taila: $20 \mathrm{ml} / \mathrm{day}, \mathrm{b}) 1 \mathrm{ft}^{2}$ thick cotton towel for Swedana, c) metallic dropper (Gokarna), d) spittoon, e) tumbler f) Saindhava Lavana, g) hot water for Kavala.

Nasya Karma was carried out in 3 consecutive steps: Purvakarma, Pradhana Karma, and Paschat Karma.

\section{Purva Karma (Pre-operative procedure)}

Patient is advised to have breakfast around $7 \mathrm{am}$. Patient was prepared for the Nasya Karma in the morning around 8.30 AM. After evacuation of bowel and bladder and once the food which was taken was completely digested, the patient was asked to lie down in supine position on the Nasya table. Therapist stood at the head end of the table. Required amount of Tila Taila was made warm indirectly over hot water bath. Face and neck of the patient was applied with Tila Taila. Forehead, eyebrows, nose, chin and maxillary area were massaged with linear thumb movements. Cheek and temporal region were massaged with palm in circular manner. Anterior of the neck was massaged by moving the palms from the base of the neck to the mandible. After massage the eyes of the patient were covered. For this, cotton dipped in water was squeezed and placed over the eyes and covered with gauze. Then Swedana was done to the face and neck. For this purpose, a towel was soaked in boiling water, the water was squeezed out, the warm towel was waved and touched on the face and neck. When there was appearance of sweat on the face, the Swedana was stopped.

\section{Pradhana Karma (Procedure)}

Then, the head of the patient was bent backwards for about 45 degrees by placing a pillow beneath the back just below the neck. Shadbindu Ghrita was made lukewarm and taken in metallic dropper. The tip of the patient's nose was elevated with the left thumb and the medicine was poured into each nostril in a single stream. Then, the patient was asked to take deep inhalation so that the medicine reaches deep inside the nose. The same was repeated in the other nostril. Then the patient was asked to spit out the medicine that reaches the throat. Swedana was repeated after administering the medicine. Mardana was done on the forehead, palms and soles of the patient. Then, the patient was made to lie down in supine position for few minutes.

\section{Pashchat Karma (Post-operative procedure)}

After that, patient was asked to wash his mouth and face with warm water. Then Kavala was performed by filling half of the mouth with lukewarm water mixed with Saindhava Lavana and moving it inside the mouth for 5 minutes. Then Haridra Dhoomapana was given. The patient was asked to inhale Dhooma through one of the nostrils by closing the other nostril with finger and exhale it through mouth. This is repeated for 3 times in one nostril. Then the same was 
repeated through the other nostril. This inhalation and exhalation of Haridra Dhooma through both nostrils was repeated for 3 times. The patient was asked to follow the regimens such as taking food that are congenial for health, residing in room devoid of breeze, avoiding exposure to dust, smoke, intake of fatty substances, exposure to sun, head bath, excessive travelling and emotional disturbances like anger, grief, etc.

\section{Results}

The severity of Vataja Pratishyaya/allergic rhinitis was 16 as per the score for allergic rhinitis of Annesi-Maesano et al which was reduced to zero after treatment. After Nasya, patient developed mild headache and heaviness of the head on the $1^{\text {st }}$ day which reduced spontaneously after 1 hour. On day 2 , there was decrease in the number of bouts of sneezes. On day 3, the number of sneezes were 10; nasal discharge was reduced. From day 4 to day 7 , patient did not have any symptoms. On $21^{\text {st }}$ day, second course of Nasya Karma was done for 7 days. In between 2 courses of Nasya, patient did not have symptoms except for 5 or 6 sneezes and scanty watery discharge. After second course of Nasya, the severity of illness was zero and there was no recurrence of symptoms observed for 4 months. There was improvement in the quality of sleep which was maintained even after second course of Nasya and during follow-up period.

\section{Discussion}

Vata is considered as prime factor in the manifestation of Vataja Pratishyaya. ${ }^{2}$ Exposure to environmental factors such as dust, domestic smoke, climatic changes, pollen, house dust mite, intake of cold water were the causative factors and would cause the symptoms immediately after exposure. Nose is considered as the gateway of head. The drug that is poured into the nasal cavity reaches various parts head through various Sira/ channels. Among 5 types of Nasya, Snehana Navana Nasya is considered as prime line of treatment in Vataja Pratishyaya. ${ }^{3}$ Abhyanga and Sweda done as Purvakarma increase blood circulation due to vasodilatation. The remaining Dosha is eliminated by Dhoomapana. As Vata is the prime Dosha in Vataja Pratishyaya, Snehana Navana Nasya is ideal in Vata predominant diseases above the clavicle. Shadbindu Ghrita is indicated in partishyaya and other types of nasal diseases in the form of Nasya. Shadbindu Ghrita contains Bhringaraja (Eclipta alba), Lavanga (Syzigium aromaticum), Yashtimadhu (Glyzirrhiza glabra), Kushta (Saussurea lappa), Shunti (Gingiber officinalis) and Ghrita (clarified butter). ${ }^{4}$ Yashtimadhu, Kushta, Shunti and Bhringaraja have antiinflammatory action. Shunti inhibits prostaglandin release and Lavanga has histamine release inhibitory activity. ${ }^{5}$ When the drug is administered in the form of Nasya, it is accessible at the affected site and the systemic absorption is minimal. Thus, high concentrations are attained at desired sites without exposing the rest of the body. The mucus membrane of the nose readily absorbs many drugs. In Shadbindu Ghrita, the drugs are processed with cow's ghee. Being a lipid soluble drug, the drug when poured through intra-nasal route achieves higher concentration in the mucus membrane of nose and diffuses quickly. The nasal mucosa provides a larger surface area and, hence, the absorption is faster. The dosage of Snehana Nasya is a debatable point. The dosage of Snehana Nasya is expressed in Bindu Pramana. Usually Bindu is translated as drops which is equal to $0.05 \mathrm{ml}$. When Bindu explained in classics is converted into mililitres $(\mathrm{ml})$ there is mismatch of dosages. Based on Bindu Pramana, Sushruta explains dosage of Snehana Navana Nasya as 16 Bindu, one Shukti (32 bindu), and one Panishukti (64 Bindu) for low, average and large dose respectively. ${ }^{6}$ When translated into millilitres, this is equal to $1 \mathrm{ml}, 2 \mathrm{ml}$ and $4 \mathrm{ml}$, respectively. Bindu refers to the amount of fluid that collected when the index finger is dipped in medicated fluid up to second interphalangeal joint. The amount of fluid collected by this method is more than one drop. In this study, the low dose is considered to fix the dose. With this dosage of 12-ml Shadbindu Ghrita poured into each nostril showed best results and there was complete relief from symptoms and signs. The dosage was well tolerated by the patient and equally safe.

\section{Conclusion}

The symptoms of Vataja Pratishyaya matches with that of allergic rhinitis. Among different treatment modalities of Vataja Pratishyaya/ Allergic Rhinitis, Nasya Karma is important procedure. Shadbindu Ghrita Nasya administered in Snehana Navana Nasya schedule is very effective in complete sustained amelioration of symptoms.

\section{Conflicts of Interest: None \\ References}

1. Shrinivasa GS. Panchakarma illustrated, $1^{\text {st }}$ edition, Chaukambha surbharati prakashan, Varanasi, 2006; 411-415.

2. Hridaya A. Uttarasthana, ch 19 , ver 2 , Chaukhamba surbharathi Prakashan, Varnasi, 2010; 287

3. Sushruta Samhita, chikitsasthana ch 40, ver 22, Reprint Edition, Chaukambha Orientalia: 2010;461

4. Anonymous, Yogaratnakara with vidyottini commentary, nasarogadhikara/1,Chaukhamba prakashan, Varanasi. 2008; 326.

5. Billore KV, Yelne MB, Dennis TJ, Chaudhari BG, Database on medicinal plants used in Ayurveda, central council for research in Ayurveda and siddha, Janakpuri, New Delhi. 4: 358.

6. Sushruta Samhita, chikitsasthana ch 40, ver 28, Reprint Edition, Chaukambha Orientalia: 2010; 461. 